\title{
The Independence of Young Children in the Care of Working Mothers
}

\author{
Mira Wida Wulan ${ }^{1, *}$, Leli Kurniawati ${ }^{2}$ \\ ${ }^{1,2}$ Department of Early Childhood Education, School of Postgraduate, Universitas Pendidikan Indonesia. \\ *Corresponding author. Email: mirawida@upi.edu.
}

\begin{abstract}
For some reasons, independence is important for children. First, it can make them more responsible in fulfilling their life needs; furthermore, it can grow their self-confidence. Independence is one of the characters that must be instilled from an early age to children, because it will have an impact until they grow up. The development of children's independence cannot be done instantly; to achieve this requires hard work by parents, especially mothers. In reality there is still negative perception in public regarding working mothers, albeit their ability to educate their children to be independent regardless of their limited time. This study was conducted because of inadequate research related to the positive impact of working mothers on early children's independence. This study is aimed to find out independence applied to children in daily life by mothers working as farm workers. Hopefully the results of this study can provide information about independence of early children nurtured by working mothers; and steps that need to be taken by working mothers to shape their children's independence.
\end{abstract}

Keywords: Independence, early children, farm worker mother.

\section{INTRODUCTION}

Children who are instilled by independence from an early age will be more inherent to it. Consequently, they will have characters that continue to develop right until they grow up. They are the ones who will become the successors of this nation, for the rise and fall of a nation is in their hands. Parents and teachers play an important role in shaping children's independence from an early age; furthermore, it is very important to be understood by both of them [1].

According to Yamin and Sanan [2], the development of independence is the result of a normative selfdevelopment process \& in line with the purpose of human life. Independence is essential for children. It can make them more responsible in complying with their needs, and it can grow their attitude. According to Puspitarini [3], self-confidence is so related to a person's sense of comfort about himself or others towards him. Building children's self-confidence is not easy, for it comes from each of them. Parents must give trust to their children, so that they are confident in their abilities. Children who are confident will try to do something over and over again albeit the failures. In contrast, children who are not confident will finish doing something when they experience breakdowns.

According to a research conducted by Prezza, et. all [4], one of the important factors that limits children's independence is the perception of parents towards social hazard. There are many factors affecting the level of independence of children, sometimes parents feel anxious about different abilities of their children. However, it does not have to be worried as long as they are still in the normal categories based on their ages and levels of development. Basically, every child is unique.

Diana Baumrind [5] mentions four different types of parenting in children's social behaviour i.e., authoritarian, permissive, authoritative, and neglectful. These parenting styles will be applied differently by each family. According to Zakiah Darajat [6] it is natural for a family as a very important means of evaluation for parents.

The socialization process is all action patterns of individuals who occupy various positions in society; these patterns, which a person meets in his daily life since he was born, become part of his personality [7]. Another factor that affects children's independence is the occupations of their parents, farm workers are one example. According to Supomo [8], a worker is a person who works for another person or a company to receive wages in an employment relationship. A farm worker is someone who is engaged in agriculture primarily by managing land to grow and maintain crops such as rice, vegetables, fruits and so forth in order to produce yields for their own or sell them to others [9]. 
Susilowati [10] states that the active role of women is not limited to their duties as wives and housewives, but also their dual role in improving welfare of their families. Now women play roles not only in reproductive and domestic activities but also in supporting their family economy, even they can carry out activities in public sectors that generate money to increase family income [11]. There are several reasons why mothers work i.e., to meet the economic needs of their family, to help their husbands increase family income and as a form of self-actualization.

According to Blowby [12], parents-children attachment has an impact on children's development. Even though the mother is an important source of childcare, she doesn't have to stay at home for twentyfour hours to build closeness with the children [13].

The research design used in this study is literature study. Literature study is the method of collecting library data, reading \& taking notes, and managing research materials. According to Danial \& Warsiah [14], literature study is research that is conducted by collecting a number of books, magazines related to research problems and objectives. This technique is carried out to reveal various theories relevant to the problem faced by the researcher as reference materials in the discussion of research results. These references can be found on books, journals, research report articles and websites on the Internet.

\section{INDEPENDENT CHILDREN}

Parents hope that their children will be independent and confident in their relationships with other people. These desires are natural and spontaneous, parents wish that their children grow up to be physically healthy in order that they become confident and independent [15].

According to Sure Start [16], interdependent relationships are seen as the key to appreciating what children do independently. Children need to support relationships through which they can develop selfconfidence and healthy self-esteem.

As the smallest community unit, family has a very strategic role in shaping the behavior or character of children according to Dzakiyah Darajat [6]. Family is the first institution in shaping the character of a child. Becoming a parent, perhaps first and foremost, is a functional status in the life cycle that includes removing \& protecting as well as caring \& representing their offspring [17]. Parents, especially mothers, are not only obliged to give birth to but also take care of $\&$ protect the children as the successors. The children's personalities depend on how they are nurtured and educated from an early age.

According to Dodge's view [18], early childhood independence can be seen from the children's ability in various ways such as physical abilities, self-confidence, responsibilities, discipline, social skills, willing to share and being able to control emotions; furthermore, according to Dodge, it can also be seen through the conditioning of children's behaviour.

Children who are independent will be sure of what they are doing when they do something. Familia [19] states that by teaching independence to children from an early age, they will be assisted to have self confidence in making decisions for themselves. Independent individuals will have the power to carry out all activities on their own without depending on others.

Family, especially a mother, has a role as the first media of socialization for children. This role is responsible for the physical and mental development of children. Mother-child interactions are proven to be very important during early childhood development, as this is a period of rapid social and emotional cognitive growth and development of brain cells [20]. Dewanggi [21] states that independence consists of children's independent eating and healthy living. Children's eating abilities include ability to wash their hands, ability to recite prayers, ability to use cutlery and the ability to eat independently. For children whose mothers work as farm workers, these are done every day by themselves without any help due to their parents' long working hours. Consequently, the children are indirectly educated to be independent, not only to eat, but also take a bath, get dressed and go to school. According to Hasan [22], independence is defined as a condition that can make an individual stand alone, and not dependent on others.

Because mothers work every day, and they have to leave at dawn, children are required to carry out their own daily activities themselves (especially farm workers whose agricultural land is in the mountains, because the distance to their plantations is relatively far). According to Hikmah [23], independence can be defined as a form of personality that is free from dependency. But even so, not all children's activities can be done alone.

According to Anggraeni [in 24], children's independence is the children's ability not to be dependent on others to the extent of their ability to think, act, and feel with responsibility for their rights and obligations that correspond with the capacity of their development stage. So, the things that children can do from an early age must be in accordance with their age and stage of development.

\section{BUILDING CHILDREN'S INDEPENDENCE}

With good communication between the whole family, children will get to know themselves and others better, and understand their own feelings as well as 
feelings experienced by others. Consequently, children will be more empathetic and independent. Effective communication can be used to build closeness with children due to short interaction time. Parents play an important role in the development of children's communication under the age of five. Children at the age of one to five years old tend to communicate by imitating people around them [25].

Give children opportunities to socialize. Give children the opportunity to make friends and hang out with their friends. When there are problems with their friends, parents are advised not to intervene directly; children are permitted to solve their own problems. However, when children are unable to solve their problems, parents can help.

Be a good role model. Parents should be seen as reliable role models, they must be able to show the ability to interact \& adapt to the environment well, solve problems successfully, and not give up quickly. Even when children become adolescents, they still see their parents as role models, reflect on them, and modify them according to their beliefs; this affects the decisions they make for their future [26].

Children's independence can be instilled and nourished both in the family and in early childhood education. The presence of preschool institutions in any forms improves all aspects of children's development, cognitive development and social behaviour including their independence. It is advised to send children to early childhood education if their age is sufficient. According to Rodriguez [in 27], there are proofs that self-control can be taught. For example, experiments have shown that young children can delay engaging in a prohibition that attracts longer activities, when they are given helpful instructions on how to distract them. Thus, improving social skills such as independent control is a legitimate goal of the early childhood education program. In addition, the school environment also affects the formation of children's independence, both through their relationships with educators and with their peers [28].

\section{CONCLUSION}

Independence is an attitude that is cumulatively acquired during development, where individuals will continue to learn to be independent in dealing with various environmental situations. Thus, according to Tjandraningtyas, [in 29], individuals will eventually be able to think and act independently. According to Geovany [30], the percentage of independent children whose mothers work is higher than those whose mothers do not work.

Independence is an aspect that must be taught and practiced from early childhood. Children who are trained to be independent from an early age will become confident and tough until they are teenagers, even until they are adults. Parenting is one of the factors that affects the independence of children. The parenting style applied in families whose mothers work as farm workers shape children's attitudes to become more independent, since children in this situation must carry out their own activities themselves. This happens every day continuously, so it will form children's independent attitude. The optimal parenting style maintains children's independence by allowing them to have some level of control [31].

Society's negative perception of working mothers, which is still around nowadays, is not true. Working mothers can still educate their children at home even with limited time. Working mothers have a dual role, and are conceptualized as mothers who have the role of cultural dualism i.e. The concept of domestic and public environment; in addition to being housewives, they also take care of their children independently [32]. Children's independence is one aspect that can be developed and formed well when they are in a family nurtured by a mother who works as a farm worker.

\section{REFERENCES}

[1] Rizkyani F, Adriany V, Syaodih E. Kemandirian anak usia dini menurut pandangan guru dan orang tua. Edukids: Jurnal Pertumbuhan, Perkembangan, dan Pendidikan Anak Usia Dini. 2019;16(2):12129.

[2] Yamin M, Sanan JS. Panduan pendidikan anak usia dini (paud). Jakarta: Gaung Persada Press Jakarta; 2012.

[3] Puspitarini. Membangun rasa percaya diri anak. Jakarta: Elex media komputindo; 2014.

[4] Miretta P, Alparone, Romana F, Cristallo, Carmela, Secchiano L. Parental perception of social risk and of positive potentiality of outdoor autonomy for children: The development of two instruments. Journal of Environmental Psychology. 2005;25(4):437-53.

[5] Desmita. Psikologi perkembangan. Bandung: PT Remaja Rosdakarya; 2012.

[6] Daradjat Z. Ilmu pendidikan Islam. Jakarta: PT Bumi Aksara;1992.

[7] Koentjaraningrat. Kebudayaan mentalitas dan pembangunan. Jakarta: PT GramedialPustaka Umum; 1997.

[8] Adniyah H, Putra A. Strategi buruh tani dalam memenuhi kebutuhan pendidikan anak di Desa Karang Baru Batu Rente Kecamatan Wanasaba Kabupaten Lombok Timur. 2017;1(2):1-6.

[9] Husodo. Pertanian mandiri. Jakarta: Penebar Swadaya; 2004. 
[10] Susilowati T. Peran serta wanita dan anak-anak dalam usaha meningkatkan penghasilan rumah tangga di Desa Marta Singa, Kabupaten Cirebon; 1998.

[11]Baso ZA. Langkah perempuan menuju tegaknya hak-hak konsumen. Makassar: Yayasan Lembaga Konsumen Sulsel [dan] the Ford Foundation; 2000.

[12] Brumariu LE, Kerns KA, Seibert A. Mother-child attachment, emotion regulation, and anxiety symptoms in middle childhood. Personal Relationships. 2012;19(3):569-85.

[13] Itabiliana, Vera K. Hadiwijoyo. Problematika ibu yang bekerja [Internet]. 2013. Available from: http://ekonomi.kompasiana.

[14]Daniel E, Warsiah. Metode penulisan karya ilmiah. Bandung. Laboratorium PKN Universitas Pendidikan Pancasila; 2009.

[15]Bowbly J. The growth of independence in the young child. Royal Society of Health Journal. 1956;76:587-91.

[16]Cameron C. Understandings of care work with young children: Reflections on children's independence in a video observation study. Childhood. 2007;14(4):467-86. DOI:10.1177/0907568207081854.

[17]Bornstein MH. Handbook of parenting: Practical issues in parenting, Vol. 5. Mahwah: Lawrence Erlbaum Associates Publishers; 2002.

[18]Dodge DT, Colker LJ, Heroman C. The Creative Curriculum $[\mathrm{R}]$ for Preschool: Developmental Continuum Assessment Toolkit for Ages 3-5. Washington, DC: Teaching Strategies, Inc.; 2001.

[19]Familia Tim Pustaka. Membuat prioritas melatih anak mandiri. Yogyakarta: Kanisius; 2006.

[20]National Research Council and Institute of Medicine. From neurons to neighbourhoods: The science of early childhood development. Committee on Integrating the Science of Early Childhood Development; 2000.

[21]Dewanggi M, Hastuti D, Hernawati N. Pengasuhan orang tua dan kemandirian anak usia 3-5 tahun berdasarkan gender di Kampung Adat Urug. Jurnal Ilmu Keluarga \& Konsumen. 2012;5(1):19-28.

[22] Hasan,A. Kamus besar bahasa Indonesia. Jakarta: Balai Pustaka; 2005.

[23] Hikmah UN. Pengaruh pola asuh orang tua terhadap kemandirian anak usia dini di RA Perwanida 01 Boyolali tahun ajaran 2011/2012 [Doctoral dissertation, Universitas Muhammadiyah Surakarta]. Surakarta: UMS; 2012.

[24] Hasanah N. Perbedaan kemandirian anak usia 5-6 tahun ditinjau dari jenis pekerjaan ayah (Petani dan Karyawan Pabrik) di Desa Bener, Kecamatan
Kepil, Kabupaten Wonosobo. BELIA: Early Childhood Education Papers. 2015;4(2):1-10.

[25]Hermoyo P. Membentuk komunikasi yang efektif pada masa perkembangan anak usia dini. Pedagogi: Jurnal Anak Usia Dini dan Pendidikan Anak Usia Dini. 2015;1(1):1-12. Available from: http://dx.doi.org/10.30651/pedagogi.v1i1.21

[26] Wiese, Freund A. Parents as role models: parental behavior affects adolescents' plans for work involvement. International Journal of Behavioral Development. 2011;35(3):218-24.

[27] Currie J. Early Childhood Education Programs. Journal of Economic Perspectives. 2001;15(2):21338 .

[28] Wiyani N. Bina karakter anak usia dini: Panduan orang tua dan guru dalam membentuk kemandirian dan kedisiplinan anak usia dini. Yogyakarta: Ar-Ruzz Media; 2016.

[29] Made RN. Pengaruh pembelajaran kontekstual dan sikap kemandirian anak terhadap kreativitas anak kelompok B TK Ganda Kerta Kumara Denpasar. Tesis. Program Studi Pendidikan Dasar. Singaraja: Program Pascasarjana, Universitas Pendidikan Ganesha; 2010.

[30] Geovany R. Perbedaan kemandirian anak usia dini ditinjau dari ibu bekerja dan ibu tidak bekerja. Jurnal Psikoborneo. 2016;4(4):464-71.

[31]Baumrind D. Effects of authoritative parental control on child behavior. Child Development. 1966 Dec 1;3794):887-7. Available from: https ://doi.org.10.2307/1126611

[32]Palupi DR, Wirastari AT. Hubungan antara motivasi berprestasi dan persepsi terhadap pola asuh orang tua dengan prestasi belajar psikologi angkatan 2010 Universitas Airlangga Surabaya. Jurnal Psikologi Pendidikan dan Perkembangan. 2013 April;2(01):1-6. 